\title{
Article \\ Foliar-Supplied Molybdenum Improves Phyto-Nutritional Composition of Leaves and Fruits of Loquat (Eriobotrya japonica Lindl.)
}

\author{
Muhammad Moaaz Ali ${ }^{1}$, Binqi Li ${ }^{1}$, Cao Zhi ${ }^{2,3, *}$, Ahmed Fathy Yousef ${ }^{1,4}\left(\mathbb{D}\right.$ and Faxing Chen ${ }^{1, *}$ \\ 1 College of Horticulture, Fujian Agriculture and Forestry University, Fuzhou 350002, China; \\ muhammadmoaazali@yahoo.com (M.M.A.); libinqi2020@126.com (B.L.); \\ ahmedfathy201161@yahoo.com (A.F.Y.) \\ 2 College of Ocean and Biochemical Engineering, Fuqing Branch of Fujian Normal University, \\ Fuqing 350300, China \\ 3 Fujian Universities and Colleges Engineering Research Center of Modern Facility Agriculture, \\ Fuqing 350300, China \\ 4 Department of Horticulture, College of Agriculture, University of Al-Azhar (Branch Assiut), \\ Assiut 71524, Egypt \\ * Correspondence: caozhi2002813@163.com (C.Z.); fxchen@fafu.edu.cn (F.C.)
}

\section{check for}

updates

Citation: Ali, M.M.; Li, B.; Zhi, C.; Yousef, A.F.; Chen, F. Foliar-Supplied Molybdenum Improves

Phyto-Nutritional Composition of Leaves and Fruits of Loquat (Eriobotrya japonica Lindl.). Agronomy 2021, 11, 892. https://doi.org/ 10.3390/agronomy11050892

Academic Editors:

Dominika Średnicka-Tober and Ewelina Hallmann

Received: 1 April 2021

Accepted: 29 April 2021

Published: 1 May 2021

Publisher's Note: MDPI stays neutral with regard to jurisdictional claims in published maps and institutional affiliations.

Copyright: (c) 2021 by the authors. Licensee MDPI, Basel, Switzerland. This article is an open access article distributed under the terms and conditions of the Creative Commons Attribution (CC BY) license (https:// creativecommons.org/licenses/by/ $4.0 /)$.

\begin{abstract}
This study was conducted to analyze the effect of molybdenum (Mo) on the level of macronutrients $(\mathrm{Mg}, \mathrm{K}, \mathrm{Ca})$, micronutrients ( $\mathrm{Na}, \mathrm{Zn}, \mathrm{B}, \mathrm{Mo}, \mathrm{Mn}, \mathrm{Fe}, \mathrm{Co}, \mathrm{Ni}, \mathrm{Cu}$ ) and toxic elements $(\mathrm{Cd}, \mathrm{Sn}, \mathrm{As}, \mathrm{Cr}, \mathrm{Hg}, \mathrm{Pb})$ in leaves and fruit tissues (peel, pulp \& seed) of loquat using inductively coupled plasma-mass spectrometry (ICP-MS). Fruits were obtained from a loquat orchard located in Fujian (Yun Xiao/Zhangzhou). Loquat leaves showed 3.99, 23.90, 57.68 and 9.79-fold increase in the concentrations of $\mathrm{Mg}, \mathrm{K}, \mathrm{Ca}$ and $\mathrm{B}$ as affected by exogenously applied Mo, while a significant $(p \leq 0.05)$ reduction was observed in $\mathrm{Na}, \mathrm{Mo}, \mathrm{Mn}, \mathrm{Co}, \mathrm{Ni}, \mathrm{Cu}, \mathrm{Sn}, \mathrm{As}, \mathrm{Cr}, \mathrm{Hg}$, and $\mathrm{Pb}$ contents. In fruit peel, Mo induced 1.05, 1.56, 2.26, 1.15, 1.39, 1.30 and 1.89-fold increase in Mg, K, Na, Zn, B, Co and $\mathrm{Ni}$, respectively, and $\mathrm{Mo}, \mathrm{Mn}, \mathrm{Fe}, \mathrm{Cu}, \mathrm{Cr}$, and $\mathrm{Pb}$ contents were reduced. Fruit pulp showed elevated contents of $\mathrm{Na}, \mathrm{B}, \mathrm{Co}, \mathrm{Ni}$, and $\mathrm{Sn}$ by 25.65, 26.57, 70.09, 12.33 and $0.99 \%$, respectively, and decreased concentrations of $\mathrm{Mg}, \mathrm{K}, \mathrm{Ca}, \mathrm{Zn}, \mathrm{Mo}, \mathrm{Mn}, \mathrm{Fe}, \mathrm{Cu}, \mathrm{Cd}$, and $\mathrm{Cr}$. Similarly, in loquat seeds, under the influence of Mo application, levels of $\mathrm{K}, \mathrm{Na}, \mathrm{Zn}, \mathrm{Fe}$, and $\mathrm{Cr}$ were uplifted by 14.75, 41.54, 12.71, 536.47 and $656.27 \%$, respectively, while $\mathrm{Mg}, \mathrm{Ca}, \mathrm{Mn}, \mathrm{Co}, \mathrm{Cu}, \mathrm{Sn}$, and $\mathrm{Hg}$ were reduced significantly $(p \leq 0.05)$. Overall, mineral concentrations detected in the leaves and fruit tissues of loquat were greatly influenced by the application of Mo. Although the concentration of Sn in fruit pulp was increased by the foliar application of Mo, the fruits were under safe limits for human consumption.
\end{abstract}

Keywords: trace elements; fertilizer; heavy metals; ICP-MS; microwave digestion; micronutrients; cadmium; principle component analysis

\section{Introduction}

Fruits and vegetables are low in energy content but have high nutritive value [1,2]. They are a rich source of vitamins, fibers, and minerals which are much essential for the human body [3]. The sufficient intake of fruits and vegetables can remove saturated fats and sugars from the body and enhance the consumption of healthy nutrients and dietary fiber [4]. To avoid certain cardiovascular diseases, it is recommended to consume $440 \mathrm{~g}$ fresh fruits and vegetables per day [5]. Heavy metals can influence the function of the nervous system, and cause mental illness by affecting the blood circulatory system [6]. Hence, it is very important to investigate the mineral contents of fruits and vegetables [7].

Loquat (Eriobotrya japonica Lindl.) is an evergreen fruit tree originated from China. It belongs to the family Rosaceae, subfamily Maloideae. It is a rich source of vitamin A, 
vitamin B6, potassium, magnesium, and dietary fiber [8]. It is a very beautiful orangecolored fruit with a mild sweet and sour taste [9]. It is most widely grown in Japan, Korea, India, Pakistan, and the south-central region of China. It is also grown as an ornamental shrub in California [10]. China is the leading producer and exporter of loquat and grows it on more than 100,000 hectares. The annual production of loquat in China reaches up to 380,000 tons [11]. More than 30 species of loquat are being grown in temperate and subtropical regions of Asia [12].

Fertilizer use is one of the main factors influencing the mineral contents of the plants [13-15]. Foliar application of fertilizers is $10-20 \%$ more influential than soil application [16-18]. Molybdenum is an essential nutrient for plant growth and is required in trace quantity. It is an integral component of nitrate reductase and nitrogenase, and vital for the nitrates' assimilation in the soil. Apart from its role in nitrate reductase, its function in higher plants is not well known [19]. Therefore, the role of Mo is closely associated with nitrogen metabolism, and its deficiency leads to $\mathrm{N}$ deficiency in plants [20]. Foliar fertilization of Mo can effectually increase internal Mo and improve the performance of molybdo-enzymes [21].

Since not much is studied about the nutritional effects of foliar-applied Mo on leaves and fruits of loquat, a field experiment was conducted at Yun Xiao, Fujian, to investigate the nutritional response of loquat to exogenous application of Mo. The contents of macronutrients $(\mathrm{Mg}, \mathrm{K}, \mathrm{Ca})$, micronutrients $(\mathrm{Na}, \mathrm{Zn}, \mathrm{B}, \mathrm{Mo}, \mathrm{Mn}, \mathrm{Fe}, \mathrm{Co}, \mathrm{Ni}, \mathrm{Cu}$ ), and heavy metals $(\mathrm{Cd}, \mathrm{Sn}, \mathrm{As}, \mathrm{Cr}, \mathrm{Hg}, \mathrm{Pb})$ in different tissues of loquat (leaf blade, fruit peel, pulp, and seed) were analyzed at different maturity stages through Inductively coupled plasma-mass spectrometry (ICP-MS).

\section{Materials and Methods}

\subsection{Plant Material}

Field experiment was carried out in a loquat orchard located at Yun Xiao, Fujian, China (235 $\left.57^{\prime} 13.5^{\prime \prime} \mathrm{N} 117^{\circ} 20^{\prime} 36.0^{\prime \prime} \mathrm{E}\right)$. Twenty-four young loquat trees ( $\mathrm{Cv}$. Jiefang zhong) were selected and tagged for periodic monitoring after foliar application of ammonium molybdate (CAS No. 12054-85-2, $\geq 99 \%$ purity, Sigma Aldrich, Milwaukee, USA). Loquat trees were $4-5.5 \mathrm{~m}$ tall with canopy diameters of $4-5 \mathrm{~m}$. The plantation distance among trees was $6 \times 6 \mathrm{~m}^{2}$, approximately. Loquat trees were systematically pruned and thinned, and fertilized with NPK (15:15:15) at concentration of $5 \mathrm{~kg}$ per plant per season for three growing seasons. The experiment contained two treatments including the control (water spray) and $0.05 \%$ ammonium molybdate. The foliar application was carried out twice at immature green fruiting stage with a 3-week interval. Each treatment consisted of four replicates, and each replicate had three trees.

\subsection{Sample Collection and Preparation}

Samples of the leaves and fruits were taken from the south-exposed tree canopy, at about 3-5 m height, at three different fruit maturity stages (i.e., immature green (IMG) (at the time of foliar spray), mature green (MG) (40 days after foliar spray) and fully ripe (FR) (70 days after foliar spray). Samples were washed (for $10 \mathrm{~s}$ approximately) with a solution of phosphate-free detergent, then with a $0.1 \mathrm{~N} \mathrm{HCl}$ solution, and finally with distilled water. Leaves, fruit peel, pulp, and seeds were dried at $70^{\circ} \mathrm{C}$, ground, and passed through a $500-\mu \mathrm{m}$ stainless-steel sieve. Soil samples were taken from the root zone of each tree, about $2 \mathrm{~m}$ from the trunk, and at two depths $(0-25$ and $25-40 \mathrm{~cm})$ using a spiral auger with a $2.5 \mathrm{~cm}$ diameter. Three sub-samples around the trunk were taken to make a composite soil sample for each tree [7]. Samples were transported to the laboratory (Institute of Subtropical Fruits, College of Horticulture, Fujian Agriculture and Forestry University, Fuzhou), oven-dried at $40^{\circ} \mathrm{C}$, and crushed to pass through a 2-mm sieve, then ground to $<60 \mu \mathrm{m}$ for element determinations $[7,22]$. The soil's structure was sandy loam with $\mathrm{pH}$ and $\mathrm{EC}$ of 6.2 and $0.396 \mathrm{dS} \mathrm{m}^{-1}$, respectively. The $\mathrm{pH}$ and EC were determined by using digital pH meter (Hanna, HI-98,107, Mauritius) and EC meter (HI-98,304, Hanna 
Instruments Inc., Mauritius), respectively. The nutritional status of the soil was determined using ICP-MS before the foliar spray of Mo (Table 1).

Table 1. Level of minerals and heavy metals in loquat growing soil before the foliar application of molybdenum.

\begin{tabular}{lll}
\hline Nutrient Class & Nutrients & Concentrations \\
\hline \multirow{3}{*}{ Macronutrients $\left(\mathrm{mg} \cdot \mathrm{Kg}^{-1}\right)$} & $\mathrm{Mg}$ & $2935.56 \pm 9.93$ \\
& $\mathrm{~K}$ & $21,499.12 \pm 104.13$ \\
& $\mathrm{Ca}$ & $2740.1 \pm 7.76$ \\
\hline & $\mathrm{Na}$ & $421.6 \pm 1.79$ \\
& $\mathrm{Zn}$ & $326.56 \pm 2.64$ \\
& $\mathrm{~B}$ & $57.23 \pm 0.54$ \\
Micronutrients $\left(\mathrm{mg} \cdot \mathrm{Kg}^{-1}\right)$ & $\mathrm{Mo}$ & $0.738 \pm 0.06$ \\
& $\mathrm{Mn}$ & $91.37 \pm 0.44$ \\
& $\mathrm{Fe}$ & $6569.07 \pm 32.26$ \\
& $\mathrm{Co}$ & $1.360 \pm 0.01$ \\
& $\mathrm{Ni}$ & $766.31 \pm 29.12$ \\
& $\mathrm{Cu}$ & $205.93 \pm 0.78$ \\
\hline Heavy Metals $\left(\mu \mathrm{g} \cdot \mathrm{Kg}^{-1}\right)$ & $\mathrm{Cd}$ & $191.75 \pm 8.45$ \\
& $\mathrm{Sn}$ & $591.47 \pm 7.15$ \\
& $\mathrm{As}$ & $333.51 \pm 2.02$ \\
& $\mathrm{Cr}$ & $7736.44 \pm 44.23$ \\
& $\mathrm{Hg}$ & $19.59 \pm 1.39$ \\
& $\mathrm{~Pb}$ & $623.18 \pm 4.22$ \\
\hline
\end{tabular}

The values in Table 1 show the mean \pm standard error of four replicates.

\subsection{Chemical Analysis}

\subsubsection{Instrumentation and Reagents}

The inductively coupled plasma mass spectrometer (Agilent7700X, Agilent, Santa Clara, CA, USA) used in this study was combined with a high-efficiency sample introduction desolvating system equipped with a quartz cyclonic spray chamber. Before each analysis, the instrument was tuned for daily performance using Agilent 7700X Sensitivity Detection Limit Solution, Agilent, USA. This is an aqueous multi-element standard solution of $\mathrm{Li}, \mathrm{Y}, \mathrm{Co}, \mathrm{Ce}$, and $\mathrm{Tl}$ for consistent sensitivity $\left({ }^{7} \mathrm{Li},{ }^{59} \mathrm{Co},{ }^{89} \mathrm{Y},{ }^{140} \mathrm{Ce},{ }^{205} \mathrm{Tl}\right)$ and minimum doubly charged and oxide species levels $\left({ }^{140} \mathrm{Ce}\right)$. The concentration of elements in the solution was $10 \mu \mathrm{g} \mathrm{L}^{-1}$. The internal standard solution (Agilent, USA) had a concentration of $0.01 \mu \mathrm{g} \mathrm{ml}{ }^{-1}$ for each element $\left({ }^{226} \mathrm{Re},{ }^{115} \mathrm{In},{ }^{73} \mathrm{Ge},{ }^{45} \mathrm{Sc}\right)$.

Standard solution $\left(1000 \mu \mathrm{g} \mathrm{L}^{-1}\right)$ for each element (i.e., $\mathrm{Mg}, \mathrm{K}, \mathrm{Ca}, \mathrm{Na}, \mathrm{Zn}, \mathrm{B}, \mathrm{Mo}$, $\mathrm{Mn}, \mathrm{Fe}, \mathrm{Co}, \mathrm{Ni}, \mathrm{Cu}, \mathrm{Cd}$, $\mathrm{Sn}, \mathrm{As}, \mathrm{Cr}, \mathrm{Hg}$, and $\mathrm{Pb}$ ) was purchased from the National Standard Material Research Centre. Nitric acid $\left(\mathrm{HNO}_{3}\right)$ used in the experiment was analytically pure, obtained from CNW Technologies $\mathrm{GmbH}$, Germany. The deionized water $\left(1.83 \times 10^{10} \mathrm{~m} \cdot \mathrm{mhos}\right)$ was prepared locally. In this experiment, the working parameters of the inductively coupled plasma mass spectrometer were optimized before the test [7].

\subsubsection{Sample Preparation}

After cleaning, glassware and a Pure Teflon (PTFE) digestion tank were soaked in $20 \%$ nitric acid $(1+4, \mathrm{~V}+\mathrm{V})$ for more than $12 \mathrm{~h}$, then rinsed with deionized water three times before use. After lyophilizing, $0.5 \mathrm{~g}$ of freeze-dried loquat tissue was added into a poly-tetra-fluoroethylene digestion tank. Then, $5 \mathrm{~mL}$ of concentrated nitric acid (analytical grade, CNW Technologies GmbH, Düsseldorf, Germany) was added. The digestion tank was gently shaken to completely immerse the sample, and microwave digestion (Mars5, HY-20-164, CEM, Matthews, NC, USA) occurred under the set conditions [7]. After microwave digestion, the solution was cooled naturally. The digestion solution was transferred to a $25-\mathrm{mL}$ volumetric flask. The blank sample (control) was prepared simultaneously. 


\subsubsection{Determination}

A single standard series solution was prepared. The mixed standard series solution and sample solution were measured by ICP-MS, and the standard curve method was used for quantification. The mixed internal standard was added to correct for matrix interference and instrument signal drift.

\subsection{Statistical Data Analysis}

Treatment allocation to loquat trees was done according to randomized complete block design (RCBD) arrangement. Collected data were subjected to analysis of variance (ANOVA), and Fisher's LSD technique was used to compare means $(p \leq 0.05)$ using the analytical software package 'Statistix 8.1'. Principal component analysis (PCA) and correlation coefficient values were determined with the Pearson (n) method using XLSTAT Ver. 2019.

\section{Results}

3.1. Leaves

\subsubsection{Macronutrients}

The foliar application of $0.05 \%$ ammonium molybdate increased the concentrations of $\mathrm{Mg}$, $\mathrm{K}$, and $\mathrm{Ca}$ in loquat leaves by $248 \%, 672 \%$, and $632 \%$ at mature green stage, while $299 \%$, $2290 \%$, and $5668 \%$ at full ripe stage as compared to control. The results showed gradual increase in macronutrients with the foliar application of $0.05 \%$ ammonium molybdate from mature green fruiting stage to full ripe stage, except in case of $\mathrm{Mg}$, when $\mathrm{Mg}$ contents were higher at mature green stage than full ripe stage (Table 2).

Table 2. Effect of foliar application of molybdenum on macronutrient concentrations in leaves of loquat.

\begin{tabular}{lllll}
\hline Fruiting Stage & Treatments & $\mathbf{M g}\left(\mathbf{m g} \cdot \mathbf{K g}^{-\mathbf{1}}\right)$ & $\mathbf{K}\left(\mathbf{m g} \cdot \mathbf{K g} \mathbf{~}^{\mathbf{1}}\right)$ & $\left.\mathbf{C a} \mathbf{( m g} \cdot \mathbf{K g}^{-\mathbf{1}}\right)$ \\
\hline IMG & Control & $342.2 \mathrm{~d}$ & $2823.1 \mathrm{c}$ & $130.7 \mathrm{c}$ \\
\hline MG & Control & $428.3 \mathrm{c}$ & $1672.1 \mathrm{~d}$ & $218.5 \mathrm{c}$ \\
& Mo & $1491.9 \mathrm{a}$ & $12912 \mathrm{~b}$ & $1600.2 \mathrm{~b}$ \\
\hline FR & Control & $284.5 \mathrm{e}$ & $859.8 \mathrm{e}$ & $177.5 \mathrm{c}$ \\
& Mo & $1136.2 \mathrm{~b}$ & $20551.1 \mathrm{a}$ & $10242.4 \mathrm{a}$ \\
\hline LSD $(p \leq 0.05)$ & & 50.49 & 385.15 & 299.07 \\
\hline
\end{tabular}

Same letters indicate non-significant difference among treatments under Fisher's least significant difference test $(p \leq 0.05)$. IMG—immature green stage; MG—-mature green stage; FR—full ripe stage. The foliar application of Mo was done at immature green stage.

\subsubsection{Micronutrients}

Overall concentration of $\mathrm{Na}$ was reduced at full ripe stage as compared to immature and mature green stage. At mature green stage, the Na level increased by $4.43 \%$ under the influence of Mo application as compared to control and recorded maximum among all observations. While at full ripe stage, Mo application reduced the Na concentration by $18 \%$ as compared to control. Zinc contents remained unchanged with the fruit maturity but significantly elevated at mature green stage in untreated plants. Plants treated with Mo exhibited a $25 \%$ decrease in $\mathrm{Zn}$ concentration at mature green stage, as compared to control, while remained unchanged at full ripe stage. The maximum level of $B\left(33.9 \mathrm{mg} \cdot \mathrm{Kg}^{-1}\right)$ was observed in loquat leaves treated with $0.05 \%$ ammonium molybdate, at full ripe stage, followed by same treatment at mature green stage. The foliar application of Mo caused gradual increase in B concentration, while untreated plants showed constant level of B in leaves with fruit maturity. The plants receiving Mo application exhibited 9.8 and 7.7-fold decrease in Mo concentration at mature green and full ripe stage, respectively. Whereas untreated plants showed significantly increased Mo level with fruit maturity. Manganese concentration in the leaves of untreated plants reduced with fruit maturity $(38.8 \%)$, whereas 
the plants treated with $0.05 \%$ ammonium molybdate showed further reduction in Mn level (Table 3).

Table 3. Micronutrient concentrations in leaves of loquat as affected by the foliar application of molybdenum.

\begin{tabular}{|c|c|c|c|c|c|c|c|c|c|c|}
\hline $\begin{array}{l}\text { Fruiting } \\
\text { Stage }\end{array}$ & Treatments & $\begin{array}{l}\mathrm{Na} \\
\left(\mathrm{mg} \cdot \mathrm{Kg}^{-1}\right)\end{array}$ & $\begin{array}{l}\mathrm{Zn} \\
\left(\mathrm{mg} \cdot \mathrm{Kg}^{-1}\right)\end{array}$ & $\begin{array}{l}\text { B } \\
\left(\mathrm{mg} \cdot \mathrm{Kg}^{-1}\right)\end{array}$ & $\begin{array}{l}\text { Mo } \\
\left(\mathrm{mg} \cdot \mathrm{Kg}^{-1}\right)\end{array}$ & $\begin{array}{l}\mathrm{Mn} \\
\left(\mathrm{mg} \cdot \mathrm{Kg}^{-1}\right)\end{array}$ & $\begin{array}{l}\mathrm{Fe} \\
\left(\mathrm{mg} \cdot \mathrm{Kg}^{-1}\right)\end{array}$ & $\begin{array}{l}\text { Co } \\
\left(\mathrm{mg} \cdot \mathrm{Kg}^{-1}\right)\end{array}$ & $\begin{array}{l}\mathrm{Ni} \\
\left(\mathrm{mg} \cdot \mathrm{Kg}^{-1}\right)\end{array}$ & $\begin{array}{l}\mathrm{Cu} \\
\left(\mathrm{mg} \cdot \mathrm{Kg}^{-1}\right)\end{array}$ \\
\hline IMG & Control & $154.1 \mathrm{~b}$ & $23.1 \mathrm{~d}$ & $2.4 \mathrm{c}$ & $0.6 \mathrm{c}$ & $126.5 a$ & $11390 \mathrm{c}$ & $4.4 \mathrm{a}$ & $4 \mathrm{~b}$ & $2.8 \mathrm{~d}$ \\
\hline \multirow[t]{2}{*}{ MG } & Control & $153.2 b$ & $33.2 \mathrm{a}$ & $2.5 \mathrm{c}$ & $1.2 \mathrm{a}$ & $119.5 b$ & $15465.8 \mathrm{a}$ & $3.3 b$ & $2.8 \mathrm{c}$ & $4.2 \mathrm{c}$ \\
\hline & Mo & $160 \mathrm{a}$ & $24.9 \mathrm{~b}$ & $15.1 b$ & $0.1 \mathrm{~d}$ & $25.1 \mathrm{e}$ & $145.6 \mathrm{~d}$ & $0.2 \mathrm{~d}$ & $9.7 \mathrm{a}$ & $13.8 \mathrm{a}$ \\
\hline \multirow[t]{2}{*}{ FR } & Control & $110 \mathrm{c}$ & $23.2 \mathrm{~cd}$ & $3.4 \mathrm{c}$ & $1.1 \mathrm{~b}$ & $77.4 \mathrm{c}$ & $12860.9 b$ & $2.2 \mathrm{c}$ & $1.7 \mathrm{~d}$ & $4.7 \mathrm{~b}$ \\
\hline & Mo & $89.4 \mathrm{~d}$ & $23.8 \mathrm{c}$ & $33.9 \mathrm{a}$ & $0.1 \mathrm{~d}$ & $32.1 \mathrm{~d}$ & $51.9 \mathrm{~d}$ & $0.1 \mathrm{e}$ & $1.0 \mathrm{e}$ & $1.8 \mathrm{e}$ \\
\hline \multicolumn{2}{|c|}{$\operatorname{LSD}(p \leq 0.05)$} & 3.68 & 0.66 & 1.02 & 0.57 & 19.07 & 405.2 & 0.67 & 0.31 & 0.41 \\
\hline
\end{tabular}

Same letters indicate non-significant difference among treatments under Fisher's least significant difference test $(p \leq 0.05)$. IMG-immature green stage; $\mathrm{MG}$ - mature green stage; FR—full ripe stage. The foliar application of Mo was done at immature green stage.

Untreated plants showed significantly increased Fe level at mature green stage $\left(15.4 \mathrm{~g} \cdot \mathrm{Kg}^{-1}\right)$ followed by full ripe stage $\left(12.86 \mathrm{~g} \cdot \mathrm{Kg}^{-1}\right)$ as compared to immature green stage $\left(11.39 \mathrm{~g} \cdot \mathrm{Kg}^{-1}\right)$. While, foliar application of Mo severely hampered the Fe concentration (106 and 247-fold reduction at mature green and full ripe stage, respectively, as compared to control). Similarly, Co concentration was also reduced with Mo application in comparison with control (12.64 and 14.42-fold reduction at mature green and full ripe stage, respectively). Whereas, untreated plants exhibited gradual decrease in Co level with fruit maturity. Nickle concentration was also reduced with fruit maturity, in untreated plants. But under the influence of Mo, maximum Ni $\left(9.7 \mathrm{mg} \cdot \mathrm{Kg}^{-1}\right)$ was recorded at mature green stage, while minimum $\left(1.0 \mathrm{mg} \cdot \mathrm{Kg}^{-1}\right)$ at full ripe stage. In case of $\mathrm{Cu}$, untreated plants exhibited steady enhancement with fruit maturity from immature green to full ripe. While Mo treated plants showed maximum $\mathrm{Cu}$ level $\left(13.8 \mathrm{mg} \cdot \mathrm{Kg}^{-1}\right)$ at mature green stage, while lowest at full ripe stage $\left(1.8 \mathrm{mg} \cdot \mathrm{Kg}^{-1}\right)$ (Table 3$)$.

\subsubsection{Heavy Metals}

Cadmium concentration in the leaves of loquat increased with increase in fruit maturity. Maximum Cd contents $\left(197.3 \mu \mathrm{g} \cdot \mathrm{Kg}^{-1}\right)$ were observed in the plants received foliar application of $0.05 \%$ ammonium molybdate, which was 2.5 -fold higher than control. In contrast with $\mathrm{Cd}$, Sn concentration decreased with increased fruit maturity, as well as with Mo application. Maximum Sn $\left(7745.3 \mu \mathrm{g} \cdot \mathrm{Kg}^{-1}\right)$ was recorded in untreated plants at mature green stage, while minimum concentration $\left(89.1 \mu \mathrm{g} \cdot \mathrm{Kg}^{-1}\right)$ was observed in Mo treated plants at same maturity stage. Foliar application of Mo significantly reduced As concentration in loquat leaves. At full ripe stage, untreated plants showed $42.3 \mathrm{mg} \cdot \mathrm{Kg}^{-1}$ As, while in comparison, plants treated with Mo exhibited only $9.2 \mu \mathrm{g} \cdot \mathrm{Kg}^{-1}$ As, which was 4700 times less than control, approximately. Similarly, Maximum $\mathrm{Cr}$ concentration $\left(4.4 \mathrm{mg} \cdot \mathrm{Kg}^{-1}\right)$ was observed in the leaves of untreated loquat plants at mature green stage, while minimum $\left(504.6 \mu \mathrm{g} \cdot \mathrm{Kg}^{-1}\right)$ found in Mo treated plants at same maturity stage. Although $\mathrm{Hg}$ concentration increased with increase in fruit maturity, Mo application significantly reduced (96 and $95.7 \%$ at mature green and full ripe stage, respectively) $\mathrm{Hg}$ contents at mature green and full ripe stage. In contrast with $\mathrm{Hg}$, $\mathrm{Pb}$ concentration decreased with increase in fruit maturity. Loquat plants treated with Mo exhibited 545 and 235-fold reduction at mature green and full ripe stage, respectively (Table 4). 
Table 4. Concentrations of heavy metals in loquat leaves affected by the foliar application of molybdenum.

\begin{tabular}{|c|c|c|c|c|c|c|c|}
\hline Fruiting Stage & Treatments & $\begin{array}{l}\mathrm{Cd} \\
\left(\mu \mathrm{g} \cdot \mathrm{Kg}^{-1}\right)\end{array}$ & $\begin{array}{l}\text { Sn } \\
\left(\mu g \cdot K^{-1}\right)\end{array}$ & $\begin{array}{l}\text { As } \\
\left(\mu g \cdot K^{-1}\right)\end{array}$ & $\mathrm{Cr}\left(\mu \mathrm{g} \cdot \mathrm{Kg}^{-1}\right)$ & $\begin{array}{l}\mathrm{Hg} \\
\left(\mu \mathrm{g} \cdot \mathrm{Kg}^{-1}\right)\end{array}$ & $\begin{array}{l}\mathrm{Pb} \\
\left(\mu \mathrm{g} \cdot \mathrm{Kg}^{-1}\right)\end{array}$ \\
\hline IMG & Control & $63.2 \mathrm{c}$ & $4673.6 c$ & $55,291.6 b$ & $2442.5 c$ & $16.1 \mathrm{c}$ & $101,903.3 a$ \\
\hline \multirow{2}{*}{ MG } & Control & $80.8 \mathrm{~b}$ & $7745.3 a$ & $58,776.8 \mathrm{a}$ & $4414.9 a$ & $34.1 \mathrm{~b}$ & $47,972.5 b$ \\
\hline & Mo & $74.2 \mathrm{~b}$ & $89.1 d$ & $22.0 \mathrm{~d}$ & $504.6 \mathrm{e}$ & $1.3 \mathrm{~d}$ & $88 \mathrm{~d}$ \\
\hline \multirow{2}{*}{ FR } & Control & $78.1 \mathrm{~b}$ & $6897.6 b$ & $42,313.7 c$ & $2788.2 b$ & $45.1 \mathrm{a}$ & $34,177.8 \mathrm{c}$ \\
\hline & Mo & $197.3 a$ & $115.9 \mathrm{~d}$ & $9.2 \mathrm{~d}$ & $1397.5 d$ & $1.9 \mathrm{~d}$ & $145.6 \mathrm{~d}$ \\
\hline $\operatorname{LSD}(p \leq 0.05)$ & & 7.93 & 340.53 & 1780 & 69.98 & 7.07 & 2486.90 \\
\hline
\end{tabular}

Same letters indicate non-significant difference among treatments under Fisher's least significant difference test $(p \leq 0.05)$. IMG-immature green stage; MG—-mature green stage; FR—full ripe stage. The foliar application of Mo was done at immature green stage.

\subsection{Fruit Peel}

\subsubsection{Macronutrients}

Magnesium concentration in fruit peel of loquat significantly reduced with increase in maturity stage. The foliar application of $0.05 \%$ ammonium molybdate caused increase in $\mathrm{Mg}$ concentrations by $12.81 \%$ and $5.76 \%$ at mature green and full ripe stage, respectively. The results showed gradual increase in $\mathrm{K}$ contents with increase in maturity stage. The foliar application of $0.05 \%$ ammonium molybdate boosted up the increasing trend of $\mathrm{K}$ by $56.5 \%$ at full ripe stage. While, Ca concentration increased with increase in fruit maturity, regardless of treatment applied. At full ripe stage, Ca concentration was 3.5-fold higher than that at mature green stage (Table 5).

Table 5. Effect of foliar application of molybdenum on macronutrient concentrations in fruit peel of loquat.

\begin{tabular}{lllll}
\hline Fruiting Stage & Treatments & $\left.\mathbf{M g} \mathbf{( m g} \cdot \mathbf{K g}^{-\mathbf{1}}\right)$ & $\mathbf{K}\left(\mathbf{m g} \cdot \mathbf{K g}^{-\mathbf{1}}\right)$ & $\mathbf{C a}\left(\mathbf{m g} \cdot \mathbf{K g} \mathbf{~}^{-\mathbf{1}}\right)$ \\
\hline MG & Control & $1449.5 \mathrm{~b}$ & $11,333.6 \mathrm{c}$ & $1765.9 \mathrm{~b}$ \\
& Mo & $1635.2 \mathrm{a}$ & $11,516.2 \mathrm{c}$ & $1750.9 \mathrm{~b}$ \\
\hline FR & Control & $1002.8 \mathrm{~d}$ & $16,802.1 \mathrm{~b}$ & $6206.9 \mathrm{a}$ \\
& Mo & $1060.5 \mathrm{c}$ & $26,297.4 \mathrm{a}$ & $6119.2 \mathrm{a}$ \\
\hline LSD $(p \leq 0.05)$ & & 41.6 & 670.44 & 347.41 \\
\hline
\end{tabular}

Same letters indicate non-significant difference among treatments under Fisher's least significant difference test $(p \leq 0.05)$. MG-mature green stage; FR-full ripe stage. The foliar application of Mo was done at immature green stage. Fruit peel was not developed enough for analysis at immature green stage.

\subsubsection{Micronutrients}

The concentration of $\mathrm{Na}$ increased at full ripe stage as compared to mature green stage. The foliar application of $0.05 \%$ ammonium molybdate boosted up the increasing trend of Na by $126.8 \%$ at full ripe stage. Similarly, a gradual increase in $\mathrm{Zn}$ contents was observed with increase in maturity stage. At full ripe stage, the $\mathrm{Zn}$ level increased by $14.5 \%$ under the influence of Mo application as compared to control and recorded maximum among all observations. Similar trend was observed in case of B concentration in fruit peel of loquat. Leaf B elevated by $39.12 \%$ at full ripe stage in Mo treated plants. Untreated plants showed 208\% increase in Mo concentration with increase in maturity (from mature green to full ripe stage). While Mo treated plants exhibited 30\% decrease in leaf Mo concentration at full ripe stage. The plants receiving Mo application exhibited 1.08 and 1.32-fold decrease in Mn concentration at mature green and full ripe stage, respectively. Whereas untreated plants showed significantly increased Mn level with fruit maturity. Iron concentration in the leaves of untreated plants reduced with fruit maturity $(56.6 \%)$. Whereas the plants treated with $0.05 \%$ ammonium molybdate showed further reduction (1.3-fold) in Mn level, at full ripe stage. Cobalt concentration increased with increase in fruit maturity, as further increase with the foliar application of Mo in comparison with control (1.4 and 1.3-fold increase at mature green and full ripe stage, respectively). Nickle 
concentration in fruit peel of untreated loquat plants also increased with increase in fruit maturity. Under the influence of $\mathrm{Mo}$, maximum $\mathrm{Ni}\left(1.3 \mathrm{mg} \cdot \mathrm{Kg}^{-1}\right)$ was recorded at full ripe stage followed by $0.9 \mathrm{mg} \cdot \mathrm{Kg}^{-1}$ at mature green stage. Regardless of treatments applied, plants exhibited significant reduction in $\mathrm{Cu}$ concentration with increasing fruit maturity. The foliar application of Mo enhanced $\mathrm{Cu}$ contents by $12.26 \%$ at mature green stage, while reduced by $3.87 \%$ at full ripe stage (Table 6).

Table 6. Micronutrient concentrations in fruit peel of loquat as affected by the foliar application of molybdenum.

\begin{tabular}{|c|c|c|c|c|c|c|c|c|c|c|}
\hline $\begin{array}{l}\text { Fruiting } \\
\text { Stage }\end{array}$ & Treatments & $\begin{array}{l}\mathrm{Na} \\
\left(\mathrm{mg} \cdot \mathrm{Kg}^{-1}\right)\end{array}$ & $\begin{array}{l}\mathrm{Zn} \\
\left(\mathrm{mg} \cdot \mathrm{Kg}^{-1}\right)\end{array}$ & $\begin{array}{l}\mathrm{B} \\
\left(\mathrm{mg} \cdot \mathrm{Kg}^{-1}\right)\end{array}$ & $\begin{array}{l}\text { Mo } \\
\left(\mathrm{mg} \cdot \mathrm{Kg}^{-1}\right)\end{array}$ & $\begin{array}{l}\mathrm{Mn} \\
\left(\mathrm{mg} \cdot \mathrm{Kg}^{-1}\right)\end{array}$ & $\begin{array}{l}\mathrm{Fe} \\
\left(\mathrm{mg} \cdot \mathrm{Kg}^{-1}\right)\end{array}$ & $\begin{array}{l}\text { Co } \\
\left(\mathrm{mg} \cdot \mathrm{Kg}^{-1}\right)\end{array}$ & $\begin{array}{l}\mathrm{Ni} \\
\left(\mathrm{mg} \cdot \mathrm{Kg}^{-1}\right)\end{array}$ & $\begin{array}{l}\mathrm{Cu} \\
\left(\mathrm{mg} \cdot \mathrm{Kg}^{-1}\right)\end{array}$ \\
\hline \multirow[t]{2}{*}{ MG } & Control & $130.1 \mathrm{c}$ & $21 c$ & $22.5 c$ & $0.1 \mathrm{c}$ & $48.8 c$ & $228.7 \mathrm{~b}$ & $0.4 \mathrm{~d}$ & $0.6 c$ & $3.4 \mathrm{~b}$ \\
\hline & Mo & $98 \mathrm{~d}$ & $21.5 c$ & $25.5 c$ & $0.1 \mathrm{c}$ & $45 c$ & $319.4 a$ & $0.5 b$ & $0.9 b$ & $3.9 \mathrm{a}$ \\
\hline \multirow[t]{2}{*}{ FR } & Control & $258 b$ & $22.9 b$ & $57.3 b$ & $0.3 \mathrm{a}$ & $59.1 \mathrm{a}$ & $99.1 \mathrm{c}$ & $0.4 \mathrm{c}$ & $0.7 \mathrm{c}$ & $2.8 \mathrm{c}$ \\
\hline & Mo & $585.4 a$ & $26.2 \mathrm{a}$ & $79.7 \mathrm{a}$ & $0.2 b$ & $44.8 \mathrm{~b}$ & $76.4 \mathrm{~d}$ & $0.6 \mathrm{a}$ & $1.3 \mathrm{a}$ & $2.7 \mathrm{~d}$ \\
\hline \multicolumn{2}{|c|}{$\operatorname{LSD}(p \leq 0.05)$} & 19.75 & 0.07 & 3.91 & 0.02 & 1.59 & 10.71 & 0.03 & 0.08 & 0.07 \\
\hline
\end{tabular}

Same letters indicate non-significant difference among treatments under Fisher's least significant difference test ( $p \leq 0.05)$. MG-mature green stage; FR-full ripe stage. The foliar application of Mo was done at immature green stage. Fruit peel was not developed enough for analysis at immature green stage.

\subsubsection{Heavy Metals}

Cadmium concentration in fruit peel of loquat increased with increase in fruit maturity. Maximum Cd contents $\left(190.5 \mu \mathrm{g} \cdot \mathrm{Kg}^{-1}\right)$ were observed in the plants received foliar application of $0.05 \%$ ammonium molybdate, which was 1.03 -fold higher than control. Similarly, Sn concentration also increased with increase in fruit maturity, as well as with Mo application. Maximum Sn $\left(1156.6 \mu \mathrm{g} \cdot \mathrm{Kg}^{-1}\right)$ was recorded in Mo treated plants at full ripe stage, while minimum concentration $\left(160.14 \mu \mathrm{g} \cdot \mathrm{Kg}^{-1}\right)$ was observed in untreated plants at green mature stage. Foliar application of Mo significantly enhanced As concentration in fruit peel of loquat. At full ripe stage, untreated plants showed $5.1 \mu \mathrm{g} \cdot \mathrm{Kg}^{-1}$ As, while in comparison, plants treated with Mo exhibited $15.52 \mu \mathrm{g} \cdot \mathrm{Kg}^{-1}$ As, which was 3 times higher than control. Maximum $\mathrm{Cr}$ concentration $\left(27.9 \mathrm{mg} \cdot \mathrm{Kg}^{-1}\right)$ was observed in fruit peel of Mo treated loquat plants at mature green stage, while minimum $\left(2.35 \mathrm{mg} \cdot \mathrm{Kg}^{-1}\right)$ found in Mo treated plants at full ripe stage. Mercury concentration remained unchanged except in the plants treated with $0.05 \%$ ammonium molybdate at full ripe stage. Maximum $\mathrm{Hg}$ contents $\left(14.3 \mu \mathrm{g} \cdot \mathrm{Kg}^{-1}\right)$ were observed in fruit peel of Mo treated loquat plants at full ripe stage. In contrast with $\mathrm{Hg}$, $\mathrm{Pb}$ concentration increased with increase in fruit maturity. In addition, loquat plants treated with Mo exhibited 2.3-fold reduction in leaf $\mathrm{Pb}$ concentration at full ripe stage (Table 7 ).

Table 7. Concentrations of heavy metals in fruit peel of loquat affected by the foliar application of molybdenum.

\begin{tabular}{|c|c|c|c|c|c|c|c|}
\hline Fruiting Stage & Treatments & $\begin{array}{l}\mathrm{Cd} \\
\left(\mu \mathrm{g} \cdot \mathrm{Kg}^{-1}\right)\end{array}$ & $\begin{array}{l}\text { Sn } \\
\left(\mu g \cdot K g^{-1}\right)\end{array}$ & $\begin{array}{l}\text { As } \\
\left(\mu \mathrm{g} \cdot \mathrm{Kg}^{-1}\right)\end{array}$ & $\mathrm{Cr}\left(\mu \mathrm{g} \cdot \mathrm{Kg}^{-1}\right)$ & $\begin{array}{l}\mathrm{Hg} \\
\left(\mu \mathrm{g} \cdot \mathrm{Kg}^{-1}\right)\end{array}$ & $\begin{array}{l}\mathrm{Pb} \\
\left(\mu \mathrm{g} \cdot \mathrm{Kg}^{-1}\right)\end{array}$ \\
\hline \multirow{2}{*}{ MG } & Control & $71.5 \mathrm{~b}$ & $160.1 \mathrm{c}$ & $5.1 \mathrm{~b}$ & $16,594.6 \mathrm{~b}$ & $2.0 \mathrm{~b}$ & $62.0 \mathrm{c}$ \\
\hline & Mo & $48.7 \mathrm{c}$ & $748.6 \mathrm{~b}$ & $19.8 \mathrm{a}$ & $27,853.3 a$ & $4.1 \mathrm{~b}$ & $74.6 \mathrm{c}$ \\
\hline \multirow[b]{2}{*}{ FR } & Control & $183.7 \mathrm{a}$ & $954.9 \mathrm{ab}$ & $5.1 b$ & $6444.6 c$ & $6.8 \mathrm{~b}$ & $1086.7 a$ \\
\hline & Mo & $190.5 a$ & $1156.6 a$ & $15.5 \mathrm{a}$ & $2375.9 d$ & $14.3 \mathrm{a}$ & $473.5 b$ \\
\hline $\operatorname{LSD}(p \leq 0.05)$ & & 20.35 & 285.97 & 5.76 & 972.50 & 2.63 & 51.17 \\
\hline
\end{tabular}

Same letters indicate non-significant difference among treatments under Fisher's least significant difference test $(p \leq 0.05)$. MG-mature green stage; FR-full ripe stage. The foliar application of Mo was done at immature green stage. Fruit peel was not developed enough for analysis at immature green stage. 


\subsection{Fruit Pulp}

\subsubsection{Macronutrients}

The foliar application of $0.05 \%$ ammonium molybdate enhanced the $\mathrm{Mg}$ concentrations at mature green stage by $8.6 \%$, and reduced at full ripe stage by $10.6 \%$. Overall $\mathrm{Mg}$ level was reduced with increase in fruit maturity. Like in case of $\mathrm{Mg}$, Mo treated plants exhibited increased $\mathrm{K}$ concentration at mature green stage by $71.3 \%$, and decrease at full ripe stage by $45.2 \%$. The trend of $\mathrm{K}$ level in untreated plants was reciprocal to that of $\mathrm{Mg}$ level i.e., $\mathrm{K}$ level was enhanced with increase in fruit maturity. Similar to Mg contents, Ca contents reduced with increase in fruit maturity. Fruit pulp Ca was reduced up to $90 \%$ at full ripe stage as compared to control. The foliar application of Mo further reduced Ca level in fruit pulp of loquat by 27.8 and $33.5 \%$ at mature green and full ripe stage, respectively (Table 8 ).

Table 8. Effect of foliar application of molybdenum on macronutrient concentrations in fruit pulp of loquat.

\begin{tabular}{lllll}
\hline Fruiting Stage & Treatments & $\mathbf{M g}\left(\mathbf{m g} \cdot \mathbf{K g}^{-\mathbf{1}}\right)$ & $\mathbf{K} \mathbf{( m g} \cdot \mathbf{K g} \mathbf{- 1}^{-\mathbf{1}}$ & $\left.\mathbf{C a} \mathbf{( m g} \cdot \mathbf{K g}^{-\mathbf{1}}\right)$ \\
\hline IMG & Control & $2466.4 \mathrm{a}$ & $5941.8 \mathrm{~d}$ & $20,412.7 \mathrm{a}$ \\
\hline MG & Control & $1932.5 \mathrm{c}$ & $5199 \mathrm{e}$ & $4820.7 \mathrm{~b}$ \\
& Mo & $2099.5 \mathrm{~b}$ & $8909.3 \mathrm{~b}$ & $3476.4 \mathrm{c}$ \\
\hline FR & Control & $1599.3 \mathrm{~d}$ & $12,814.7 \mathrm{a}$ & $1933.3 \mathrm{~d}$ \\
& Mo & $1429.3 \mathrm{e}$ & $7013.5 \mathrm{c}$ & $1285 \mathrm{e}$ \\
\hline LSD $(p \leq 0.05)$ & & 38.02 & 199.46 & 699.25 \\
\hline
\end{tabular}

Same letters indicate non-significant difference among treatments under Fisher's least significant difference test ( $p \leq 0.05)$. IMG-immature green stage; MG-mature green stage; FR-full ripe stage. The foliar application of Mo was done at immature green stage.

\subsubsection{Micronutrients}

Overall concentration of Na remained unchanged at full ripe stage as compared to immature green stage, and reduced with respect to mature green stage. At mature green stage, the Na level increased (2.64-fold) as compared to immature green stage and recorded maximum among all observations. At same maturity stage, the foliar application of Mo reduced the Na concentration to same level as immature green stage had. While at full ripe stage, Mo application enhanced the Na concentration by $25.65 \%$ as compared to control. Zinc contents were reduced with the fruit maturity. Minimum Zn contents $(21.58 \mathrm{mg}$. $\mathrm{Kg}^{-1}$ ) were observed at mature green stage in Mo treated plants. Plants treated with Mo exhibited $17 \%$ decrease in $\mathrm{Zn}$ concentration at full ripe stage, as compared to control. The maximum level of $B\left(36.3 \mathrm{mg} \cdot \mathrm{Kg}^{-1}\right)$ was observed in fruit pulp of loquat treated with $0.05 \%$ ammonium molybdate, at mature green stage, followed by same treatment at full ripe stage. The untreated plants showed slight but significant increase in B contents in fruit pulp with fruit maturity. The foliar application of Mo caused further increase in B concentration. The plants receiving Mo application exhibited 1.37 and 1.01-fold decrease in Mo concentration at mature green and full ripe stage, respectively. The untreated plants also showed significant decrease in Mo level with fruit maturity. Manganese concentration in the fruit pulp of untreated plants reduced with fruit maturity (up to $82 \%$ ). Whereas, the plants treated with $0.05 \%$ ammonium molybdate showed slight but significant increase in $\mathrm{Mn}$ level at mature green stage, and further reduction at full ripe stage as compared to control (Table 9). 
Table 9. Micronutrient concentrations in fruit pulp of loquat as affected by the foliar application of molybdenum.

\begin{tabular}{|c|c|c|c|c|c|c|c|c|c|c|}
\hline $\begin{array}{l}\text { Fruiting } \\
\text { Stage }\end{array}$ & Treatments & $\begin{array}{l}\mathrm{Na} \\
\left(\mathrm{mg} \cdot \mathrm{Kg}^{-1}\right)\end{array}$ & $\begin{array}{l}\mathrm{Zn} \\
\left(\mathrm{mg} \cdot \mathrm{Kg}^{-1}\right)\end{array}$ & $\begin{array}{l}\text { B } \\
\left(\mathrm{mg} \cdot \mathrm{Kg}^{-1}\right)\end{array}$ & $\begin{array}{l}\text { Mo } \\
\left(\mathrm{mg} \cdot \mathrm{Kg}^{-1}\right)\end{array}$ & $\begin{array}{l}\mathrm{Mn} \\
\left(\mathrm{mg} \cdot \mathrm{Kg}^{-1}\right)\end{array}$ & $\begin{array}{l}\mathrm{Fe} \\
\left(\mathrm{mg} \cdot \mathrm{Kg}^{-1}\right)\end{array}$ & $\begin{array}{l}\text { Co } \\
\left(\mathrm{mg} \cdot \mathrm{Kg}^{-1}\right)\end{array}$ & $\begin{array}{l}\mathrm{Ni} \\
\left(\mathrm{mg} \cdot \mathrm{Kg}^{-1}\right)\end{array}$ & $\begin{array}{l}\mathrm{Cu} \\
\left(\mathrm{mg} \cdot \mathrm{Kg}^{-1}\right)\end{array}$ \\
\hline IMG & Control & $73.1 \mathrm{c}$ & $41.7 \mathrm{a}$ & $12.1 \mathrm{~d}$ & $11.2 \mathrm{a}$ & $283.5 \mathrm{a}$ & $68.9 \mathrm{~b}$ & $0.2 \mathrm{e}$ & $0.4 \mathrm{e}$ & $2.5 \mathrm{~d}$ \\
\hline \multirow[t]{2}{*}{ MG } & Control & $193.4 \mathrm{a}$ & $26.5 \mathrm{c}$ & $18.1 \mathrm{c}$ & $0.1 \mathrm{~b}$ & $71.4 \mathrm{c}$ & $69.2 \mathrm{~d}$ & $0.3 \mathrm{~d}$ & $10.6 a$ & $8.5 a$ \\
\hline & Mo & $74.5 \mathrm{c}$ & $21.5 \mathrm{~d}$ & $36.3 a$ & $0.1 \mathrm{c}$ & $80.3 \mathrm{~b}$ & $57.2 \mathrm{c}$ & $0.4 \mathrm{~b}$ & $3 d$ & $4.1 \mathrm{c}$ \\
\hline \multirow[t]{2}{*}{ FR } & Control & $\begin{array}{l}78.8 \mathrm{c} \\
99 \mathrm{~b}\end{array}$ & $\begin{array}{l}30.1 \mathrm{~b} \\
24.9 \mathrm{c}\end{array}$ & $\begin{array}{l}17.6 c \\
22.3 b\end{array}$ & $0.1 \mathrm{c}$ & $50.7 d$ & $76.1 \mathrm{a}$ & $0.3 \mathrm{c}$ & $4.3 \mathrm{c}$ & $6 \mathrm{~b}$ \\
\hline & 1010 & 990 & $24.9 \mathrm{C}$ & 2 & $0.1 \mathrm{C}$ & 4 & 5 & ba & b & $4.2 \mathrm{C}$ \\
\hline
\end{tabular}

Same letters indicate non-significant difference among treatments under Fisher's least significant difference test $(p \leq 0.05)$. IMG-immature green stage; MG-mature green stage; FR-full ripe stage. The foliar application of Mo was done at immature green stage.

Untreated plants showed slight but significant increase in Fe level at full ripe stage $\left(76.1 \mathrm{mg} \cdot \mathrm{Kg}^{-1}\right)$ as compared to immature green stage $\left(68.9 \mathrm{mg} \cdot \mathrm{Kg}^{-1}\right)$. While, foliar application of Mo significantly hampered the Fe concentration (1.21 and 1.38-fold reduction at mature green and full ripe stage, respectively, as compared to control). Cobalt concentration was observed increasing with increased fruit maturity. Molybdenum application induced 1.4 and 1.7-fold increase in Co level of loquat fruit pulp at mature green and full ripe stage, respectively. The maximum Ni concentration $\left(10.6 \mathrm{mg} \cdot \mathrm{Kg}^{-1}\right)$ was observed in fruit pulp of untreated plants at mature green stage. The foliar application of Mo induced 3.5-fold reduction in $\mathrm{Ni} \mathrm{level} \mathrm{at} \mathrm{mature} \mathrm{green} \mathrm{stage.} \mathrm{While} \mathrm{at} \mathrm{full} \mathrm{ripe} \mathrm{stage,} \mathrm{Ni} \mathrm{contents} \mathrm{were}$ elevated by $12.33 \%$ as compared to control. In case of $\mathrm{Cu}$, the maximum level $\left(8.5 \mathrm{mg} \cdot \mathrm{Kg}^{-1}\right)$ was observed in fruit pulp of untreated plants at mature green stage. The foliar application of Mo induced 2 and 1.4-fold reduction in Cu level at mature green and full ripe stage, respectively (Table 9).

\subsubsection{Heavy Metals}

Cadmium concentration in fruit pulp of loquat decreased with increase in fruit maturity. Maximum Cd contents $\left(298.1 \mu \mathrm{g} \cdot \mathrm{Kg}^{-1}\right)$ were observed in the untreated plants at immature green stage, which was 4.3 -fold higher than those at full ripe stage. Foliar application of Mo induced 1.8 and 1.86-fold reduction in Cd level at mature green and full ripe stage. In contrast with $\mathrm{Cd}$, Sn concentration increased with increased fruit maturity, as well as with Mo application. Maximum Sn $\left(101.8 \mu \mathrm{g} \cdot \mathrm{Kg}^{-1}\right)$ was recorded in Mo treated plants at full ripe stage, while minimum concentration $\left(58.4 \mu \mathrm{g} \cdot \mathrm{Kg}^{-1}\right)$ was observed in untreated plants at mature green stage. Foliar application of Mo significantly reduced As concentration in fruit pulp of loquat at mature green stage, while observed unchanged at full ripe stage as compared to control. At mature green stage, untreated plants showed $21.7 \mu \mathrm{g} \cdot \mathrm{Kg}^{-1}$ As, while in comparison, plants treated with Mo exhibited only $0.5 \mu \mathrm{g} \cdot \mathrm{Kg}^{-1}$ As, which was 47 times less than control, approximately. Similarly, Maximum $\mathrm{Cr}$ concentration $\left(1.5 \mathrm{mg} \cdot \mathrm{Kg}^{-1}\right)$ was observed in fruit pulp of untreated loquat plants at immature green stage, while minimum $\left(535.1 \mu \mathrm{g} \cdot \mathrm{Kg}^{-1}\right)$ found in Mo treated plants at full ripe stage. Mercury concentration remained unchanged throughout fruit maturity. Molybdenum application significantly enhanced $\mathrm{Hg}$ contents in fruit pulp of loquat at mature green stage, while recorded unchanged at full ripe stage as compared to control. Regardless of treatment applied, $\mathrm{Pb}$ concentration decreased with increase in fruit maturity (Table 10). 
Table 10. Concentrations of heavy metals in fruit pulp of loquat affected by the foliar application of molybdenum.

\begin{tabular}{|c|c|c|c|c|c|c|c|}
\hline Fruiting Stage & Treatments & $\begin{array}{l}\mathrm{Cd} \\
\left(\mu \mathrm{g} \cdot \mathrm{Kg}^{-1}\right)\end{array}$ & $\begin{array}{l}\text { Sn } \\
\left(\mu g \cdot K g^{-1}\right)\end{array}$ & $\begin{array}{l}\text { As } \\
\left(\mu g \cdot K^{-1}\right)\end{array}$ & $\mathrm{Cr}\left(\mu \mathrm{g} \cdot \mathrm{Kg}^{-1}\right)$ & $\begin{array}{l}\mathrm{Hg} \\
\left(\mu \mathrm{g} \cdot \mathrm{Kg}^{-1}\right)\end{array}$ & $\begin{array}{l}\mathrm{Pb} \\
\left(\mu \mathrm{g} \cdot \mathrm{Kg}^{-1}\right)\end{array}$ \\
\hline IMG & Control & 298.1a & $86.8 \mathrm{~b}$ & $30.6 a$ & $1539.3 a$ & $1.5 b$ & $4432.2 \mathrm{a}$ \\
\hline \multirow{2}{*}{ MG } & Control & $173.1 \mathrm{~b}$ & $58.4 \mathrm{c}$ & $21.7 \mathrm{~b}$ & $849.5 b$ & $1.3 \mathrm{~b}$ & $230.4 b$ \\
\hline & Mo & $95.7 \mathrm{c}$ & $90.6 \mathrm{~b}$ & $0.5 c$ & $569.0 \mathrm{~d}$ & $3.4 \mathrm{a}$ & $140.4 b$ \\
\hline \multirow{2}{*}{ FR } & Control & $69.3 d$ & $100.8 \mathrm{a}$ & $22.0 \mathrm{ab}$ & $619.8 c$ & $1.8 \mathrm{~b}$ & $40.8 b$ \\
\hline & Mo & $37.1 \mathrm{e}$ & $101.8 \mathrm{a}$ & $23.6 \mathrm{ab}$ & $535.1 \mathrm{~d}$ & $2.0 \mathrm{~b}$ & $61.4 \mathrm{~b}$ \\
\hline $\operatorname{LSD}(p \leq 0.05)$ & & 12.56 & 7.77 & 8.78 & 42.17 & 0.76 & 220.72 \\
\hline
\end{tabular}

Same letters indicate non-significant difference among treatments under Fisher's least significant difference test $(p \leq 0.05)$. IMG-immature green stage; MG-mature green stage; FR-full ripe stage. The foliar application of Mo was done at immature green stage.

\subsection{Seed}

\subsubsection{Macronutrients}

The Mg and Ca concentration in untreated loquat seeds increased by 91 and $46.4 \%$ at mature green stage, and decreased by 52 and $90 \%$, respectively at full ripe stage as compared to immature green stage. While seeds of plants receiving foliar application of Mo exhibited 1.4 and 1.5-fold reduction in $\mathrm{Mg}$ and Ca contents at full ripe stage, respectively. The $\mathrm{K}$ concentration showed reciprocal trend to the $\mathrm{Mg}$ and $\mathrm{Ca}$ concentrations. Magnesium concentration in untreated loquat seeds decreased by $48.74 \%$ at mature green stage, and increased by $35.27 \%$ at full ripe stage as compared to immature green stage. This fluctuation indicated an extraordinary reduction in $\mathrm{K}$ level $\left(10,956.3 \mathrm{mg} \cdot \mathrm{Kg}^{-1}\right)$ at mature green stage. While seeds of plants receiving foliar application of Mo exhibited 1.03 and 1.14-fold increment in $\mathrm{K}$ contents at mature green and full ripe stage, respectively (Table 11).

Table 11. Effect of foliar application of molybdenum on macronutrient concentrations in seeds of loquat.

\begin{tabular}{|c|c|c|c|c|}
\hline Fruiting Stage & Treatments & $\mathrm{Mg}\left(\mathrm{mg} \cdot \mathrm{Kg}^{-1}\right)$ & $\mathrm{K}\left(\mathrm{mg} \cdot \mathrm{Kg}^{-1}\right)$ & $\mathrm{Ca}\left(\mathrm{mg} \cdot \mathrm{Kg}^{-1}\right)$ \\
\hline IMG & Control & $1350.6 \mathrm{c}$ & $21,376.3 a$ & $10,651.1 b$ \\
\hline \multirow[t]{2}{*}{ MG } & Control & $2581.4 a$ & $10,956.3 d$ & $15,588.3 a$ \\
\hline & Mo & $2227.4 b$ & $11,377.1 \mathrm{~d}$ & $15,282.8 \mathrm{a}$ \\
\hline \multirow[t]{2}{*}{ FR } & Control & $1231.5 \mathrm{~d}$ & $14,821.4 \mathrm{c}$ & $1461.7 \mathrm{c}$ \\
\hline & Mo & $849.8 \mathrm{e}$ & $17,008.9 b$ & $951.1 d$ \\
\hline $\operatorname{LSD}(p \leq 0.05)$ & & 37.37 & 384.61 & 471.19 \\
\hline
\end{tabular}

Same letters indicate non-significant difference among treatments under Fisher's least significant difference test $(p \leq 0.05)$. IMG-immature green stage; MG-mature green stage; FR-full ripe stage. The foliar application of Mo was done at immature green stage.

\subsubsection{Micronutrients}

Sodium contents in seeds were observed to be reduced with increase in fruit maturity of loquat. While, Mo application significantly improved the Na percentage in loquat seeds at mature green (195\%) and full ripe stage (41.5\%) as compared to control. Zinc concentration in untreated loquat seeds increased by $62.2 \%$ at mature green stage, and decreased by $70 \%$ at full ripe stage as compared to immature green stage. This fluctuation indicated an extraordinary enhancement in $\mathrm{Zn}$ level $\left(37 \mathrm{mg} \cdot \mathrm{Kg}^{-1}\right)$ at mature green stage. While seeds of plants receiving foliar application of Mo exhibited 1.38 and 1.12-fold enhancement in $\mathrm{Zn}$ contents at mature green and full ripe stage, respectively. Regardless of treatment applied, $\mathrm{B}$ contents remained unchanged with the fruit maturity, but significantly supressed at mature green stage in untreated plants. The maximum level of Mo $\left(4.7 \mathrm{mg} \cdot \mathrm{Kg}^{-1}\right)$ was observed in loquat seeds treated with $0.05 \%$ ammonium molybdate, at mature green stage. All other observations exhibited non-significant difference among each other. Manganese concentration in untreated loquat seeds increased by $668.4 \%$ at mature green stage, and 
decreased by $93.4 \%$ at full ripe stage as compared to immature green stage. This fluctuation indicated an extraordinary enhancement in Mn level $\left(402.2 \mathrm{mg} \cdot \mathrm{Kg}^{-1}\right)$ at mature green stage. While seeds of plants receiving foliar application of Mo exhibited 2.02 and 1.85-fold reduction in Mn contents at mature green and full ripe stage, respectively (Table 12).

Table 12. Micronutrient concentrations in seeds of loquat as affected by the foliar application of molybdenum.

\begin{tabular}{|c|c|c|c|c|c|c|c|c|c|c|}
\hline $\begin{array}{l}\text { Fruiting } \\
\text { Stage }\end{array}$ & Treatments & $\begin{array}{l}\mathrm{Na} \\
\left(\mathrm{mg} \cdot \mathrm{Kg}^{-1}\right)\end{array}$ & $\begin{array}{l}\mathrm{Zn} \\
\left(\mathrm{mg} \cdot \mathrm{Kg}^{-1}\right)\end{array}$ & $\begin{array}{l}\text { B } \\
\left(\mathrm{mg} \cdot \mathrm{Kg}^{-1}\right)\end{array}$ & $\begin{array}{l}\text { Mo } \\
\left(\mathrm{mg} \cdot \mathrm{Kg}^{-1}\right)\end{array}$ & $\begin{array}{l}\mathrm{Mn} \\
\left(\mathrm{mg} \cdot \mathrm{Kg}^{-1}\right)\end{array}$ & $\begin{array}{l}\mathrm{Fe} \\
\left(\mathrm{mg} \cdot \mathrm{Kg}^{-1}\right)\end{array}$ & $\begin{array}{l}\text { Co } \\
\left(\mathrm{mg} \cdot \mathrm{Kg}^{-1}\right)\end{array}$ & $\begin{array}{l}\mathrm{Ni} \\
\left(\mathrm{mg} \cdot \mathrm{Kg}^{-1}\right)\end{array}$ & $\begin{array}{l}\mathrm{Cu} \\
\left(\mathrm{mg} \cdot \mathrm{Kg}^{-1}\right)\end{array}$ \\
\hline IMG & Control & $92.8 \mathrm{c}$ & $22.8 \mathrm{c}$ & $18.7 \mathrm{ab}$ & $0.3 b$ & $52.3 c$ & $45.9 d$ & $0.2 \mathrm{~d}$ & $1.6 a$ & $1.8 \mathrm{~d}$ \\
\hline \multirow[t]{2}{*}{ MG } & Control & $73.6 \mathrm{~d}$ & $37.0 \mathrm{~b}$ & $15.2 b$ & $0.08 \mathrm{~b}$ & $402.2 \mathrm{a}$ & $66.3 d$ & $0.6 a$ & $0.4 \mathrm{c}$ & $2.3 c$ \\
\hline & Mo & 217.3a & $51.1 \mathrm{a}$ & $19.7 \mathrm{a}$ & $4.7 \mathrm{a}$ & $198.5 b$ & $91.3 \mathrm{c}$ & $0.2 \mathrm{~d}$ & $0.2 \mathrm{~d}$ & $1.6 \mathrm{e}$ \\
\hline \multirow[t]{2}{*}{ FR } & Control & $73.6 \mathrm{~d}$ & $10.7 \mathrm{e}$ & $21.2 \mathrm{a}$ & $0.1 b$ & $26.4 \mathrm{~d}$ & $205.4 b$ & $0.5 b$ & $1.4 \mathrm{~b}$ & $2.9 \mathrm{a}$ \\
\hline & Mo & $104.2 \mathrm{~b}$ & $12.1 \mathrm{~d}$ & $18.8 \mathrm{ab}$ & $0.1 b$ & $14.2 \mathrm{e}$ & $1307.4 a$ & $0.2 \mathrm{c}$ & $1.4 \mathrm{~b}$ & $2.5 b$ \\
\hline \multicolumn{2}{|c|}{$\operatorname{LSD}(p \leq 0.05)$} & 3.93 & 1.18 & 0.76 & 0.16 & 11.21 & 56.61 & 0.02 & 0.15 & 0.07 \\
\hline
\end{tabular}

Same letters indicate non-significant difference among treatments under Fisher's least significant difference test $(p \leq 0.05)$. IMG-immature green stage; MG-mature green stage; FR-full ripe stage. The foliar application of Mo was done at immature green stage.

Untreated plants showed significantly increased Fe level at full ripe stage $\left(205.4 \mathrm{mg} \cdot \mathrm{Kg}^{-1}\right)$ followed by mature green stage $\left(66.3 \mathrm{mg} \cdot \mathrm{Kg}^{-1}\right)$ as compared to immature green stage $\left(45.9 \mathrm{mg} \cdot \mathrm{Kg}^{-1}\right)$. While, foliar application of Mo significantly enhanced the Fe concentration (6.36-fold) at full ripe stage as compared to control. Cobalt concentration in untreated loquat seeds increased by $176.4 \%$ at mature green stage, and decreased by $18.35 \%$ at full ripe stage as compared to immature green stage. This fluctuation indicated an extraordinary enhancement in Co level $\left(0.6 \mathrm{mg} \cdot \mathrm{Kg}^{-1}\right)$ at mature green stage. While seeds of plants receiving foliar application of Mo exhibited 3.06 and 1.75-fold reduction in Co contents at mature green and full ripe stage, respectively. The Ni concentration showed reciprocal trend to the Co concentration. Nickel concentration in untreated loquat seeds decreased by $71.82 \%$ at mature green stage, and increased by $196.83 \%$ at full ripe stage as compared to immature green stage. This fluctuation indicated an extraordinary reduction in Ni level $\left(0.4 \mathrm{mg} \cdot \mathrm{Kg}^{-1}\right)$ at mature green stage. While seeds of plants receiving foliar application of Mo exhibited 1.9-fold reduction in Ni contents at mature green stage. In case of $\mathrm{Cu}$, untreated plants exhibited steady enhancement with fruit maturity from immature green to full ripe. While Mo treated plants showed maximum Cu level $\left(2.5 \mathrm{mg} \cdot \mathrm{Kg}^{-1}\right)$ at full ripe stage, while lowest at mature green stage $\left(1.7 \mathrm{mg} \cdot \mathrm{Kg}^{-1}\right)$ (Table 12).

\subsubsection{Heavy Metals}

Cadmium concentration in the seeds of loquat decreased with increase in fruit maturity. Maximum Cd contents $\left(268.2 \mu \mathrm{g} \cdot \mathrm{Kg}^{-1}\right)$ were observed in the plants received foliar application of $0.05 \%$ ammonium molybdate, which was non-significantly different than control. In contrast with $\mathrm{Cd}, \mathrm{Sn}$ concentration increased with increase in fruit maturity, while decreased with Mo application. Maximum Sn $\left(484.2 \mu \mathrm{g} \cdot \mathrm{Kg}^{-1}\right)$ was recorded in untreated plants at full ripe stage, while minimum concentration $\left(80.24 \mu \mathrm{g} \cdot \mathrm{Kg}^{-1}\right)$ was observed in untreated plants at immature green stage. Foliar application of Mo significantly reduced As concentration in loquat seeds at mature green stage. At full ripe stage, untreated plants showed $4.4 \mu \mathrm{g} \cdot \mathrm{Kg}^{-1} \mathrm{As}$, while in comparison, plants treated with Mo exhibited $9.09 \mu \mathrm{g} \cdot \mathrm{Kg}^{-1}$ As. In contrast, Maximum $\mathrm{Cr}$ concentration $\left(80.7 \mathrm{mg} \cdot \mathrm{Kg}^{-1}\right)$ was observed in the seeds of Mo treated loquat plants at full ripe stage, while minimum $\left(1.3 \mathrm{mg} \cdot \mathrm{Kg}^{-1}\right)$ found in untreated plants at immature green stage. Molybdenum application significantly increased $\mathrm{Hg}$ contents by $78.2 \%$ at mature green stage, while reduced by $68.8 \%$ at full ripe stage. Similarly, loquat plants treated with Mo exhibited 1.65-fold enhanced $\mathrm{Pb}$ at mature green as compared to control. While, there was no significant change in $\mathrm{Pb}$ contents observed by Mo application at full ripe stage (Table 13). 
Table 13. Concentrations of heavy metals in loquat seeds affected by the foliar application of molybdenum.

\begin{tabular}{|c|c|c|c|c|c|c|c|}
\hline Fruiting Stage & Treatments & $\begin{array}{l}\mathrm{Cd} \\
\left(\mu \mathrm{g} \cdot \mathrm{Kg}^{-1}\right)\end{array}$ & $\begin{array}{l}\text { Sn } \\
\left(\mu g \cdot K g^{-1}\right)\end{array}$ & $\begin{array}{l}\text { As } \\
\left(\mu g \cdot K^{-1}\right)\end{array}$ & $\mathrm{Cr}\left(\mu \mathrm{g} \cdot \mathrm{Kg}^{-1}\right)$ & $\begin{array}{l}\mathrm{Hg} \\
\left(\mu \mathrm{g} \cdot \mathrm{Kg}^{-1}\right)\end{array}$ & $\begin{array}{l}\mathrm{Pb} \\
\left(\mu \mathrm{g} \cdot \mathrm{Kg}^{-1}\right)\end{array}$ \\
\hline IMG & Control & $187.4 \mathrm{~b}$ & $80.2 \mathrm{e}$ & $87.2 \mathrm{a}$ & $1310.9 \mathrm{c}$ & $1.1 \mathrm{~d}$ & $160.2 \mathrm{c}$ \\
\hline \multirow{2}{*}{ MG } & Control & $265.7 a$ & $194.9 \mathrm{~d}$ & $91.1 \mathrm{a}$ & $2196.4 c$ & $5.3 b$ & $4228.9 b$ \\
\hline & Mo & $268.2 a$ & $239.4 \mathrm{c}$ & $44.2 \mathrm{~b}$ & $4332.6 c$ & $9.4 \mathrm{a}$ & $6998.8 \mathrm{a}$ \\
\hline \multirow{2}{*}{ FR } & Control & $66.3 c$ & $484.2 \mathrm{a}$ & $4.4 \mathrm{c}$ & $10,675.2 b$ & $2.1 \mathrm{~d}$ & $248.2 c$ \\
\hline & Mo & $54.0 \mathrm{c}$ & $287.3 b$ & $9.1 \mathrm{c}$ & $80,732.7 a$ & $3.5 c$ & $147.6 \mathrm{c}$ \\
\hline $\operatorname{LSD}(p \leq 0.05)$ & & 16.21 & 22.39 & 10.42 & 3927 & 1.32 & 233.4 \\
\hline
\end{tabular}

Same letters indicate non-significant difference among treatments under Fisher's least significant difference test $(p \leq 0.05)$. IMG-immature green stage; MG-mature green stage; FR-full ripe stage. The foliar application of Mo was done at immature green stage.

\subsection{Principle Component Analysis}

To delineate the effect of multiple variables, Principal Component Analysis (PCA) among Mo treatment and nutritional concentrations in leaves and fruits of loquat was determined (Figure 1). Factor F1, covering 39.81\% variability in data (eigenvalue 7.167), showed highest squared cosine values of $\mathrm{Mg}, \mathrm{K}, \mathrm{Ca}, \mathrm{Fe}, \mathrm{Cu}, \mathrm{Sn}, \mathrm{As}, \mathrm{Hg}$ and $\mathrm{Pb}$ in leaves with both treatments (Control and $0.05 \%$ ammonium molybdate) at immature green and full ripe stage, as well as in seeds at immature green stage, suggesting positive relation of aforementioned response and treatment variables. Second factor, covering $24.06 \%$ variability in data (eigenvalue 4.331), showed highest squared cosine values of $\mathrm{Zn}$, Mo, $\mathrm{Mn}$ and Cd in fruit peel with both treatments at mature green stage, in fruit pulp both treatments at immature green stage and Mo treatment at mature green and full ripe stage, in seed both treatments at mature green stage, and control treatment at full ripe stage. Third factor of PCA, covering $12.59 \%$ variability in data (eigenvalue 2.268 ), showed highest cosine values of $\mathrm{B}, \mathrm{Ni}$ and $\mathrm{Cu}$ in leaves with foliar application of Mo at mature green stage, in fruit peel both treatments at full ripe stage, in pulp control treatment at mature green and full ripe stage. Factor 4, covering $9.44 \%$ variability in data (eigenvalue 1.7), showed highest cosine values of $\mathrm{Na}$ and $\mathrm{Cr}$ in loquat seeds with foliar application of Mo at full ripe stage. Thus, PCA delineated the effect of treatment variables on macro-nutrients, micro-nutrients and heavy metals in leaves and fruit tissues of loquat.

Biplot (axes F1 and F2: $63.88 \%$ )

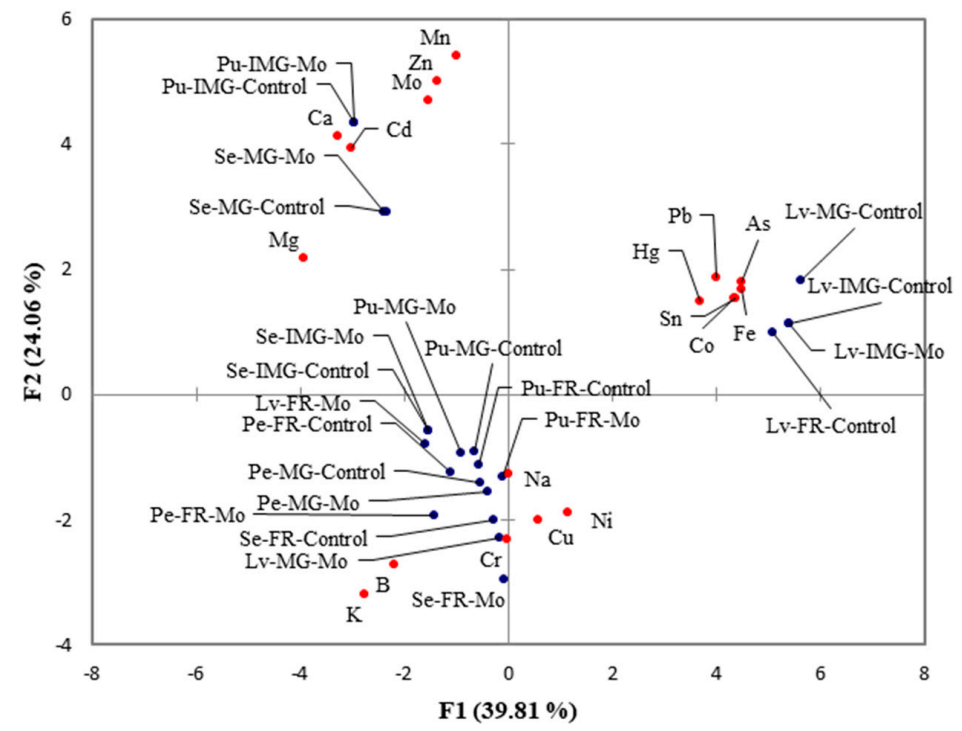

Figure 1. Principle component analysis among Mo application and nutritional concentrations in leaves and fruits of loquat. Lv-leaves; Pe-fruit peel, Pu-fruit pulp, Se-seed, IMG-immature green stage, MG-mature green stage, FR-full ripe stage. 


\section{Discussion}

There were differences in the concentrations of nutrients and heavy metals between leaves and fruit tissues of loquat observed on three different maturity stages i.e., immature green, mature green, and full ripe stage (Tables 1-13). The nutrient concentrations in plant tissues are known to fluctuate throughout the growing season due to environmental factors (i.e., soil water, temperature) between periods of adequate soil supply of micronutrients and periods of insufficient soil supply of the applied micronutrient [23,24]. Therefore, in present study, the fluctuation in concentrations of nutrients was observed throughout maturity of loquat. Current study suggests that $\mathrm{Mg}, \mathrm{K}$, and Ca content increased by the foliar application of $0.05 \%$ ammonium molybdate in leaves of loquat. In plants, $\mathrm{K}, \mathrm{Na}$, $\mathrm{Ca}$, and $\mathrm{Mg}$ not only maintain the balance of potential energy, but are also components or key supporting elements of important functional enzymes [25]. The obtained results regarding the effect of foliar applied Mo on leaf $\mathrm{Mg}, \mathrm{K}$, and Ca content are in line with earlier reported studies. It has been reported that Mo application improved leaf $\mathrm{Mg}, \mathrm{K}$, and Ca content of sunflower by $12 \%, 3 \%$, and $6 \%$, respectively [26]. Foliar application of $1.5 \mathrm{~cm} \cdot \mathrm{L}^{-1}$ Mo increased the concentrations of $\mathrm{Mg}, \mathrm{K}$, and Ca by $6.6 \%, 5 \%$, and $9.8 \%$ in the leaves of 'Le-Conte' pear. Same treatment, when applied along with $3 \mathrm{~g} \cdot \mathrm{L}^{-1} \mathrm{Fe}$, enhanced the $\mathrm{Mg}, \mathrm{K}$, and Ca level by $18.3 \%, 12.3 \%$, and $30.3 \%$ in the leaves of 'Le-Conte' pear [27].

Molybdenum is an essential element for plant growth and plays important role in different metabolic processes. Moreover, it has vital role in the function of nitrate and nitrite reductase [21]. After the uptake of nitrates by roots, these nitrates are readily moveable in plants and their accumulation occurs in vacuoles. However, nitrates reduction to ammonium $\left(\mathrm{NH}_{4}{ }^{+}\right)$is necessary to support the synthesis of organic compounds and proteins in plants [28]. The nitrates reduction to $\mathrm{NH}_{4}{ }^{+}$is supported by different enzymes in two steps. In first step, the transformation of $\mathrm{NO}_{3}{ }^{-}$to $\mathrm{NO}_{3}{ }^{-}$is occurred by nitrate reductase in cytoplasm. In second step, the conversion of $\mathrm{NO}_{2}{ }^{-}$to $\mathrm{NO}_{4}{ }^{+}$is occurred in proplastids or chloroplasts by nitrite reductase [29]. The reduction of $\mathrm{NO}_{3}{ }^{-}$to $\mathrm{NO}_{2}{ }^{-}$depends upon several factors including plant species, plant carbohydrates, activity of nitrate and nitrite reductase, and environmental conditions i.e., light, $\mathrm{pH}, \mathrm{CO}_{2}$, and $\mathrm{NO}_{3}{ }^{-}$[30]. The foliar application of Mo is highly associated with $\mathrm{N}$ accumulation in plant leaves. The absence of Mo promotes nitrates accumulation and indicates less $\mathrm{N}$ assimilation by the plants [28]. Exogenously applied Mo improved Mo concentration in plant tissues of 'Le-Conte' pear [27], grapes (Cv. Merlot) [31], sunflower [26], peanut [32] and lettuce [28]. Our findings are in line with aforementioned studies, suggesting that foliar application of $0.05 \%$ ammonium molybdate increased the concentration of Mo in seeds of loquat. The reduction of Mo in leaves can be associated with the availability $\mathrm{NH}_{4}{ }^{+}$along with Mo. It has been reported earlier than the availability of $\mathrm{NH}_{4}{ }^{+}$lowers the activity of nitrate reductase causing Mo deficiency in plants [33]. A similar observation was made by Phillips [34] who reported lower molybdenum concentrations in leaf petioles from previously treated grape vines than untreated controls. Furthermore, the data presented by Williams et al. [35] over a three-year period also showed a successive decline in leaf molybdenum concentration.

Foliar application of $0.05 \%$ ammonium molybdate severely hampered the Fe concentration in leaves, fruit peel, and pulp of loquat. While, in 'Le-Conte' pear, Fe concentration was significantly increased with Mo application [27]. Similarly, Zn concentration was observed increased in fruit peel and seed under the influence of foliar-applied Mo. Our findings are in corroboration with Abd-El-Latif et al. [27] who also reported a remarkable increase in $\mathrm{Zn}$ concentration of pear leaves under the influence of $1.5 \mathrm{~cm} . \mathrm{L}^{-1} \mathrm{Mo}$. Abd-El-Latif et al. [27] also reported an increase in Mn concentration as the results of Mo application on 'Le-Conte' pear, which was in contrast with our findings. Similarly, synergism between Mn and Mo was found in canola [36]

Loquat leaves have high medicinal value and have been used as folk medicines for thousands of years. Cough, inflammation, chronic bronchitis, cancer, and diabetes are treated with the extract of loquat leaves in Chinese folk medicine [37]. Loquat leaves are rich in phenolics and triterpenes [38]. Concerning human health, it is very important to 
investigate the effect of foliar-supplied nutrients on phytonutritional composition of loquat leaves as the uptake of elements by plants can be associated with the availability of other elements. The quadrupole inductively coupled plasma mass spectrometry (ICP-MS) is the most suitable method for the determination of trace elements in fruits and vegetables and is prevailed as the most appropriate practice for clinical quantification [39-42]. The element detection through ICP-MS has become a predominant methodology, because of its rapidity, determination limits, and the sample quantity needed for analysis [43].

Schroeder and Balassa [44] were the first to identify that fertilizers were implicated in raising heavy metal concentrations in food crops. Studies of heavy metals uptake by plants have often revealed their accumulation at a level, toxic to human health. More than $70 \%$ of cadmium intake by humans is sourced from fruits and vegetables [45]. According to the findings of various scientists, cadmium is a mobile element in the soil whereas it is immobile in plants, that is why it is found abundantly in plant roots [46-48]. The results indicate a significant decrease in cadmium concentration in loquat fruits from mature green to fruit ripening stage. The reduction of cadmium concentration over time in leaves of holm oak and fruit pulp of olives has also been reported earlier [22]. Although Cd is an immobile element in plant body, its reduction under the influence of Mo has also been reported in several studies $[49,50]$.

Loquat fruit is one of those fruit crops which are highly sensitive to quality of irrigation water [51]. Arsenic (As) is a heavy metal that is present in the groundwater of many areas of the world and can contaminate fruits through irrigation water [52]. There are many studies reported on high-level toxicity of arsenic in fruits, vegetables, and cereal crops irrigated on arsenic-contaminated water [53]. Our findings of the arsenic concentration in different plant tissues of loquat indicate that the toxicity of arsenic reduced with the progression from mature green stage to full ripe stage. The results are in corroboration with Madejon et al. [22] who reported reduction in the concentration of As with the passage of time in leaves and fruits of olive and holm oak. Overall, results suggested that Mo improved nutritional composition of loquat leaves and fruit tissues and alleviated the toxicity of heavy metals.

\section{Conclusions}

Concerning human health, it is very important to investigate the effect of foliarsupplied nutrients on heavy metal accumulation in fruits as the uptake of elements by plants can be associated with the availability of other elements. Therefore, this study was conducted to confirm the concentration and availability of phytonutrients in loquat leaves and fruit tissues under the influence of the foliar application of molybdenum. Exogenous application of molybdenum proved to be successful for improving mineral nutrition of loquat, as evidenced by increased macro and micro-nutrients and decreased heavy metals in leaves and fruit tissues. There is need to investigate Mo-modulated molecular mechanisms regulating minerals uptake and accumulation in leaves and fruit tissues.

Author Contributions: Conceptualization, M.M.A. and F.C.; methodology, M.M.A.; data curation, M.M.A. and A.F.Y.; writing—original draft preparation, M.M.A.; writing-review and editing, A.F.Y., B.L., C.Z. and F.C.; supervision, F.C.; project administration, F.C.; funding acquisition, F.C. All authors have read and agreed to the published version of the manuscript.

Funding: This research was funded by "Fujian Provincial Development and Reform Commission, grant number 2013-772" and "Key Laboratory of Loquat Germplasm Innovation and Utilization, Fujian Province University (Putian), grant number 102/KLh19010A".

Institutional Review Board Statement: Not applicable.

Informed Consent Statement: Not applicable.

Data Availability Statement: Not applicable.

Acknowledgments: Authors would like to thank the remarkable efforts of laboratory staff of "Institute of Subtropical Fruits, Fujian Agriculture and Forestry University, Fuzhou 350002, China". 
Conflicts of Interest: The authors declare no conflict of interest.

\section{References}

1. Ali, M.M.; Anwar, R.; Yousef, A.F.; Li, B.; Luvisi, A.; De Bellis, L.; Aprile, A.; Chen, F. Influence of Bagging on the Development and Quality of Fruits. Plants 2021, 10, 358. [CrossRef] [PubMed]

2. Siddique, W.; Hasan, M.U.; Shah, M.S.; Ali, M.M.; Hayat, F.; Mehmood, A. Impact of blanching and packaging materials on postharvest quality and storability of fresh spinach. J. Hortic. Sci. Technol. 2021, 4, 7-12. [CrossRef]

3. Slavin, J.L.; Lloyd, B. Health Benefits of Fruits and Vegetables. Adv. Nutr. 2012, 3, 506-516. [CrossRef] [PubMed]

4. Pem, D.; Jeewon, R. Fruit and vegetable intake: Benefits and progress of nutrition education interventions-narrative review article. Iran. J. Public Health 2015, 44, 1309-1321. [PubMed]

5. WHO. Food Safety; WHO: Geneva, Switzerland, 2015.

6. Hajeb, P.; Sloth, J.J.; Shakibazadeh, S.; Mahyudin, N.A.; Afsah-Hejri, L. Toxic Elements in Food: Occurrence, Binding, and Reduction Approaches. Compr. Rev. Food Sci. Food Saf. 2014, 13, 457-472. [CrossRef] [PubMed]

7. Ali, M.M.; Anwar, R.; Shafique, M.W.; Yousef, A.F.; Chen, F. Exogenous Application of Mg, Zn and B Influences Phyto-Nutritional Composition of Leaves and Fruits of Loquat (Eriobotrya japonica Lindl.). Agronomy 2021, 11, 224. [CrossRef]

8. Badenes, M.L.; Canyamas, T.; Romero, C.; Soriano, J.M.; Martínez, J.; Llácer, G. Genetic diversity in european collection of loquat (Eriobotrya japonica Lindl.). Acta Hortic. 2003, 620, 169-174. [CrossRef]

9. Tian, S.; Qin, G.; Li, B. Loquat. In Postharvest Biology and Technology of Tropical and Subtropical Fruits; Elsevier: Amsterdam, The Netherlands, 2011; p. 444.

10. LaRue, R.G. Loquat Fact Sheet. Available online: http://fruitsandnuts.ucdavis.edu/dsadditions/Loquat_Fact_Sheet/ (accessed on 30 January 2020).

11. Tian, S.; Li, B.; Ding, Z. Physiological properties and storage technologies of loquat fruit. Fresh Prod. 2007, 1, 76-81.

12. Lu, Z.M.; Zhang, Z.L.; Wu, W.X.; Li, W.H. Effect of low temperatures on postharvest loquat fruit. Acta Hortic. 2007, 750, 483-486. [CrossRef]

13. Corelli-Grappadelli, L.; Lakso, A.N. Fruit developemtn in deciduous tree crops as affected by physiological factors and environmental conditions (keynote). Acta Hortic. 2004, 52, 425-441. [CrossRef]

14. Bálint, A.F.; Kovács, G.; Erdei, L.; Sutka, J. Comparison of the $\mathrm{Cu}, \mathrm{Zn}, \mathrm{Fe}, \mathrm{Ca}$ and $\mathrm{Mg}$ contents of the grains of wild, ancient and cultivated wheat species. Cereal Res. Commun. 2001, 29, 375-382. [CrossRef]

15. Hattori, H.; Chino, M. Growth, cadmium, and zinc contents of wheat grown on various soils enriched with cadmium and zinc. In Plant Nutrition; J.B. Metzler: Sttutgart, Germany, 2001; pp. 462-463.

16. Zaman, Q.U.; Schumann, A.W. Nutrient Management Zones for Citrus Based on Variation in Soil Properties and Tree Performance. Precis. Agric. 2006, 7, 45-63. [CrossRef]

17. Javed, T.; Ali, M.M.; Shabbir, R.; Anwar, R.; Afzal, I.; Mauro, R.P. Alleviation of Copper-Induced Stress in Pea (Pisum sativum L.) through Foliar Application of Gibberellic Acid. Biology 2021, 10, 120. [CrossRef] [PubMed]

18. Ali, M.M.; Waleed Shafique, M.; Gull, S.; Afzal Naveed, W.; Javed, T.; Yousef, A.F.; Mauro, R.P. Alleviation of Heat Stress in Tomato by Exogenous Application of Sulfur. Horticulturae 2021, 7, 21. [CrossRef]

19. Cecílio-Filho, A.B.; López-Aguilar, M.A.; Rugeles-Reyes, S.M.; Mendoza-Cortez, J.W. Molybdenum dosage and application timing in sweet corn. Rev. Colomb. Ciencias Hortícolas 2019, 13, 219-227. [CrossRef]

20. Pollock, V.V.; Conover, R.C.; Johnson, M.K.; Barber, M.J. Bacterial expression of the molybdenum domain of assimilatory nitrate reductase: Production of both the functional molybdenum-containing domain and the nonfunctional tungsten analog. Arch. Biochem. Biophys. 2002, 403, 237-248. [CrossRef]

21. Kaiser, B.N.; Gridley, K.L.; Ngaire Brady, J.; Phillips, T.; Tyerman, S.D. The Role of Molybdenum in Agricultural Plant Production. Ann. Bot. 2005, 96, 745-754. [CrossRef]

22. Madejon, P.; Maranon, T.; Mmurillo, J. Biomonitoring of trace elements in the leaves and fruits of wild olive and holm oak trees. Sci. Total Environ. 2006, 355, 187-203. [CrossRef]

23. Mundorf, T.; Wortmann, C.; Shapiro, C.; Paparozzi, E. Time of Day Effect on Foliar Nutrient Concentrations in Corn and Soybean. J. Plant. Nutr. 2015, 38, 2312-2325. [CrossRef]

24. Stewart, Z.P.; Paparozzi, E.T.; Wortmann, C.S.; Jha, P.K.; Shapiro, C.A. Effect of Foliar Micronutrients (B, Mn, Fe, Zn) on Maize Grain Yield, Micronutrient Recovery, Uptake, and Partitioning. Plants 2021, 10, 528. [CrossRef]

25. Lin, L.; Zhou, W.; Dai, H.; Cao, F.; Zhang, G.; Wu, F. Selenium reduces cadmium uptake and mitigates cadmium toxicity in rice. J. Hazard. Mater. 2012, 235-236, 343-351. [CrossRef] [PubMed]

26. Škarpa, P.; Kunzová, E.; Zukalová, H. Foliar fertilization with molybdenum in sunflower (Helianthus annuus L.). Plant. Soil Environ. 2013, 59, 156-161. [CrossRef]

27. Abd-El-Latif, F.M.; Bakry, K.A.; El-Gioushy, S.F.; Hussein, A.M.; Mohamed, M.S. Effect of Foliar Spray with Molybdenum and Iron on Vagative Growth and Nutritional Status of Pear Trees. J. Plant. Prod. 2020, 11, 655-659. [CrossRef]

28. Steiner, F.; Zoz, T.; Zuffo, A.M.; Machado, P.P.; Zoz, J.; Zoz, A. Foliar application of molybdenum enhanced quality and yield of crispleaf lettuce (Lactuca sativa L., cv. Grand Rapids). Acta Agronómica 2018, 67, 73-78. [CrossRef]

29. Rosales, E.P.; Iannone, M.F.; Groppa, M.D.; Benavides, M.P. Nitric oxide inhibits nitrate reductase activity in wheat leaves. Plant. Physiol. Biochem. 2011, 49, 124-130. [CrossRef] 
30. Mokhele, B.; Zhan, X.; Yang, G.; Zhang, X. Review: Nitrogen assimilation in crop plants and its affecting factors. Can. J. Plant. Sci. 2012, 92, 399-405. [CrossRef]

31. Longbottom, M.L.; Dry, P.R.; Sedgley, M. Effects of sodium molybdate foliar sprays on molybdenum concentration in the vegetative and reproductive structures and on yield components of Vitis vinifera cv. Merlot. Aust. J. Grape Wine Res. 2010, 16, 477-490. [CrossRef]

32. Soares Filho, S.I.B.; Lazarini, E.; Orioli Júnior, V.; Bernardes, J.V.S. Sowing dates and molybdenum foliar application for two peanut cultivars. Rev. Ciência Agrícola 2020, 18, 27. [CrossRef]

33. Wyse, S. Nitrate reductase activity in plant species of varied spatial association with acidic soils beneath Agathis australis. New Zeal. J. Bot. 2014, 52, 213-223. [CrossRef]

34. Phillips, T. Molybdenum Nutrition of Vitis Vinifera cv. Merlot Foliar Absorption, Translocation and An Enzymic Assay for Deficiency; The University of Adelaide: Adelaide, Australia, 2004.

35. Williams, C.M.J.; Maier, N.A.; Bartlett, L. Effect of Molybdenum Foliar Sprays on Yield, Berry Size, Seed Formation, and Petiolar Nutrient Composition of "Merlot" Grapevines. J. Plant. Nutr. 2005, 27, 1891-1916. [CrossRef]

36. Brennan, R.F.; Bolland, M.D.A. Foliar spray experiments identify no boron deficiency but molybdenum and manganese deficiency for canola grain production on acidified sandy gravel soils in southwestern Australia. J. Plant. Nutr. 2011, 34, 1186-1197. [CrossRef]

37. Li, M.; Liang, Y. Li Shizhen and The Grand Compendium of Materia Medica. J. Tradit. Chin. Med. Sci. 2015, 2, 215-216. [CrossRef]

38. Zhang, W.; Zhao, X.; Sun, C.; Li, X.; Chen, K. Phenolic Composition from Different Loquat (Eriobotrya japonica Lindl.) Cultivars Grown in China and Their Antioxidant Properties. Molecules 2015, 20, 542-555. [CrossRef] [PubMed]

39. Bressy, F.C.; Brito, G.B.; Barbosa, I.S.; Teixeira, L.S.G.; Korn, M.G.A. Determination of trace element concentrations in tomato samples at different stages of maturation by ICP OES and ICP-MS following microwave-assisted digestion. Microchem. J. 2013, 109, 145-149. [CrossRef]

40. Sahan, Y.; Basoglu, F.; Gucer, S. ICP-MS analysis of a series of metals (Namely: Mg, Cr, Co, Ni, Fe, Cu, Zn, Sn, Cd and Pb) in black and green olive samples from Bursa, Turkey. Food Chem. 2007, 105. [CrossRef]

41. Chudzinska, M.; Baralkiewicz, D. Application of ICP-MS method of determination of 15 elements in honey with chemometric approach for the verification of their authenticity. Food Chem. Toxicol. 2011, 49, 2741-2749. [CrossRef]

42. Llorent-Martínez, E.J.; de Córdova, M.L.F.; Ruiz-Medina, A.; Ortega-Barrales, P. Analysis of 20 trace and minor elements in soy and dairy yogurts by ICP-MS. Microchem. J. 2012, 102, 23-27. [CrossRef]

43. De Blas Bravo, I.; Sanz Castro, R.; López Riquelme, N.; Tormo Díaz, C.; Apraiz Goyenaga, D. Optimization of the trace element determination by ICP-MS in human blood serum. J. Trace Elem. Med. Biol. 2007, 21, 14-17. [CrossRef]

44. Schroeder, H.A.; Balassa, J.J. Cadmium: Uptake by Vegetables from Superphosphate in Soil. Science 1963, 140, 819-820. [CrossRef]

45. Chen, Y.; Li, T.Q.; Han, X.; Ding, Z.L.; Yang, X.E.; Jin, Y.F. Cadmium accumulation in different pakchoi cultivars and screening for pollution-safe cultivars. J. Zhejiang Univ. Sci. B 2012, 13, 494-502. [CrossRef]

46. Rahman, M.A.; Hasegawa, H. High levels of inorganic arsenic in rice in areas where arsenic-contaminated water is used for irrigation and cooking. Sci. Total Environ. 2011, 409, 4645-4655. [CrossRef] [PubMed]

47. Sridhara Chary, N.; Kamala, C.T.; Samuel Suman Raj, D. Assessing risk of heavy metals from consuming food grown on sewage irrigated soils and food chain transfer. Ecotoxicol. Environ. Saf. 2008, 69, 513-524. [CrossRef]

48. Lebeau, T.; Bagot, D.; Jézéquel, K.; Fabre, B. Cadmium biosorption by free and immobilised microorganisms cultivated in a liquid soil extract medium: Effects of Cd, pH and techniques of culture. Sci. Total Environ. 2002, 291, 73-83. [CrossRef]

49. Han, Z.; Wei, X.; Wan, D.; He, W.; Wang, X.; Xiong, Y. Effect of Molybdenum on Plant Physiology and Cadmium Uptake and Translocation in Rape (Brassica napus L.) under Different Levels of Cadmium Stress. Int. J. Environ. Res. Public Health 2020, 17, 2355. [CrossRef] [PubMed]

50. Nie, Z.J.; Hu, C.X.; Sun, X.C.; Tan, Q.L.; Liu, H.E. Effects of molybdenum on ascorbate-glutathione cycle metabolism in Chinese cabbage (Brassica campestris L. ssp. pekinensis). Plant. Soil 2007, 295, 13-21. [CrossRef]

51. Burló-Carbonell, F.; Carbonell-Barrachina, A.; Vidal-Roig, A.; Mataix-Beneyto, J. Effects of irrigation water quality on loquat plant nutrition: Sensitivity of loquat plant to salinity. J. Plant. Nutr. 1997, 20, 119-130. [CrossRef]

52. Heitkemper, D.T.; Kubachka, K.M.; Halpin, P.R.; Allen, M.N.; Shockey, N.V. Survey of total arsenic and arsenic speciation in us-produced rice as a reference point for evaluating change and future trends. Food Addit. Contam. Part. B Surveill. 2009, 2, 112-120. [CrossRef] [PubMed]

53. Farid, A.T.M.; Roy, K.C.; Hossain, K.M.; Sen, R. A Study of Arsenic Contaminated Irrigation Water and its Carried Over Effect on Vegetable. In Proceedings of the International Symposium on Fate of Arsenic in the Environment, Dhaka, Bang-ladesh, 5-6 February 2003; pp. 113-121. 